\title{
Ecotourism and primate habituation: Behavioral variation in two groups of white-faced capuchins (Cebus capucinus) from Costa Rica
}

\author{
Shasta E. Webb ${ }^{1} \&$ Michael B. McCoy ${ }^{2}$ \\ 1. Macalester College, 1600 Grand Avenue, St. Paul, MN 55105-1899; webbshasta@gmail.com \\ 2. Associated Colleges of the Midwest, Costa Rican Office, San Pedro de Montes de Oca, Costa Rica; \\ mmccoycolton@yahoo.com
}

Received 20-III-2014. Corrected 20-IV-2014. Accepted 15-V-2014.

\begin{abstract}
The increase of ecotourism operations within Costa Rica during the last 20yrs has brought more and more humans into close, direct contact with several wildlife species. One of these species is the white-faced capuchin (Cebus capucinus), highly gregarious, and with exposure over time, willing to come into close vicinity of humans and their developments. Such contact has its advantages and disadvantages for the ecotourism industry. We observed white-faced monkeys in order to assess the impact of human presence and development on monkey behavior, with a focus on aggressive, affiliative, and foraging behaviors in Curú Wildlife Refuge (CWR), located in Puntarenas, Costa Rica, and to ascertain the degree of over-habituation of capuchin populations at CWR. Though there exists no discrete behavioral parameters that measure over-habituation, it can be defined as an extreme state of habituation in which non-human primates not only lose fear of humans, but also actively include humans in social interactions or treat them as a food resource. We used instantaneous focal animal and group scan sampling during 8wks in March and April 2012. Two groups (approximately 20-30 individuals each) of capuchins were observed; the first near the tourist development at the Southwestern area of CWR, representing a habituated population that regularly foraged, rested, and groomed in the presence of humans. The second, was observed in the Northeastern area of CWR, did not visit the center of human activity and exhibited fear of humans. The habituated group exhibited significantly fewer instances of threatened behavior in response to human presence $(\mathrm{p}<0.0001)$ than the non-habituated group, and spent significantly more time eating and foraging $(\mathrm{p}<0.0001)$. While the habituated monkeys at CWR may not be over-habituated, they could become that way as development, especially ecotourism, increases. Over-habituation is a problem that affects capuchins in certain ecotourism sites in Costa Rica. It is critical that the consequences of habituation be studied more carefully, primarily in areas where ecotourism operations draw visitors to wildlife habitats. Rev. Biol. Trop. 62 (3): 909-918. Epub 2014 September 01.
\end{abstract}

Key words: Cebus capucinus, Costa Rica, ecotourism, habituation, over-habituation, white-faced capuchin.

Historically, primatologists have largely ignored anthropogenic influences on nonhuman primate communities. Leading primatologists in the field have admitted to previously viewing humans as "pesky" and "insignificant" aspects of the environment. In recent years however, primatologists and biological anthropologists have shifted their thinking: humans are a critical factor in any primate environment and must be assessed for potential influence on primate health, behavior, and long-term viability, especially in cases where the primates are already assessed as threatened, endangered, or critically endangered.

To determine potential anthropogenic threats to primates, this paper focuses on habituation - the gradually lessened response to an outside stimulus - and over-habituation, defined here as the behavioral state in which a primate has not only lost fear of humans but also includes humans in social interactions or interacts with humans as food sources. The primary examination of this topic is framed within ecotourism, which theoretically attempts to 
attract visitors to and educate them about pristine natural environments while simultaneously creating low-impact development, providing economic benefits to the community that lives with and protects wildlife, as well as promoting peaceful coexistence. Ecotourism in practice is often flawed because it is largely unregulated, but conceptually has the potential for success in wildlife conservation (Buchsbaum, 2004).

This paper represents a case study examining two groups of wild white-faced capuchins (Cebus capucinus) that inhabit Curú Wildlife Refuge and Hacienda, a small, private ecotourist site in Costa Rica. Behavioral differences between groups of capuchins are expected due to differential contact with humans and human development. In particular, behavioral differences regarding fear-related activity (e.g. monkey fear of humans) and foraging behavior (e.g. if monkeys spend more time occupied by fear-related behavior, they will spend less time foraging for food) are expected.

Despite the worldwide reputation of Costa Rica as a leader in ecotourism (Honey, 2003; Buchsbaum, 2004; Gall \& Hobby, 2007) recent studies have revealed that ecotourism has been far less effective in protecting significant ecological resources or benefitting local communities than originally thought. Stem, Lassoie, Lee, Deshler, and Schelhas (2003) focused on Corcovado National Park in Costa Rica and reported "mixed" findings regarding the effectiveness of ecotourism as a conservation and community development tool. The study resulted in several recommendations regarding ecotourism, including that "ecotourism would be most effective as a component of a broader conservation strategy," referring to the need for firmer and more transparent planning and policies on the national level (Stem et al., 2003). It should be noted that in comparison to other ways in which Costa Ricans financially sustain themselves (e.g. forest plantations/logging, cattle ranching, agriculture, etc.) ecotourism remains the most environmentally sustainable option. Despite the abundant issues with ecotourism, tourists continue to visit Costa Rica for opportunities to see and interact with its abundant wildlife. This paper examines the potential impacts of the interactions between humans and primates on the behavior patterns of white-faced capuchins in an ecotourism setting.

\section{MATERIALS AND METHODS}

Study site: Privately owned Curú National Wildlife Refuge and Hacienda (CWR) located in Puntarenas, Costa Rica $\left(9^{\circ} 47^{\prime} 36.24^{\prime \prime} \mathrm{N}\right.$, $84^{\circ} 55^{\prime} 21.36^{\prime \prime} \mathrm{W}$ ), is considered a successful endeavor in ecotourism, conservation, and wildlife and land management (Schutt \& Vaughan, 1995). Curú Wildlife Refuge covers approximately $14.94 \mathrm{~km}^{2}$ and receives about $1600 \mathrm{~mm}$ of precipitation annually. Ninety percent of precipitation falls during the wet season, from May to November (IMN, 2012). In 1995, approximately $30 \%$ of CWR was altered environment, including pastures, forest plantations, living fence rows, and fruit plantations (Schutt \& Vaughan, 1995). The unaltered $70 \%$ was made up of natural forests, including upland dry, lowland evergreen, mangrove and beach-marine forest. Curu Wildlife Refuge attracts both domestic and foreign tourists and researchers to its immense biodiversity and relatively accessible location. For the current study, the previously agrarian region of CWR is referred to as the 'Finca Side' and the forested portion of CWR as the 'Ceiba Side' due to the presence of ceiba (Ceiba pentandra) trees. Additionally, in the agricultural areas, natural riparian forests, palm-lined canals, and living fencerows formed vegetation corridors (Schutt, \& Vaughan, 1995). For more detailed information about CWR, see Schutt and Vaughan, 1995 and www.curuwildliferefuge.com.

Study species: Our study species, known commonly as the white-faced capuchin, whitefaced monkey, or white-headed monkey, belongs to the taxonomic subfamily Cebinae. Cebines, which also include squirrel monkeys (genus Saimiri), are easily recognizable due to their long-time use in the film industry, presence in the pet trade, and use in street performances 
as sources of income (Jack, 2010). Because of their large range and relatively dense populations, white-faced capuchins are a well-studied species (e.g. Hall, 2000; Rose, 2000; Williams, \& Vaughan, 2001; Perry et al., 2003; Vogel, 2005; Crofoot et al., 2009).

White-faced capuchins are a "least concern" species as determined by the IUCN, meaning they have been evaluated for threats to long-term survival of the species and appear not to be at risk (IUCN, 2012). They have a broad range from Honduras to Ecuador and can survive in a wide variety of habitats - from primary forests in the Neotropics, to highly fragmented secondary or successional forests, to semi-developed areas of human habitation (Hall, 2000; Van Hulle \& Vaughan, 2009). Male capuchins range in size from $1.3-4.8 \mathrm{~kg}$ $(\bar{x}=3.0 \mathrm{~kg})$ and females range in size from $1.4-3.4 \mathrm{~kg}(\bar{x}=2.3 \mathrm{~kg})$. Males typically weigh $19.5 \%-27 \%$ more than females. Social structure is multi-male multi-female with one alpha male and alpha female. Social relationships within troops, which average 16.4 members, are maintained primarily via affiliative behaviors such as grooming, continued proximity, and coalition formation between preferred partners (Jack, 2010).

Data collection: Two groups of whitefaced monkeys were observed for this study, each consisting of 20-30 individuals. The Finca group foraged and spent diurnal hours in forest patches and corridors in the formerly agricultural part of CWR. Finca monkeys were located farther away from the center of human development and activity at CWR, and rarely entered into close proximity to humans other than myself. The Ceiba group visited the center of human development two to three times per day to eat fruit provided to them by the one of the owners of CWR. The center of human development was the primary area frequented by visitors who wanted to see monkeys. I recorded distance of each monkey group from the farm headquarters (main buildings) at $5 \mathrm{~min}$ intervals during observation of each group (Rose, 2000).

Observations were daily alternated between the Finca or Ceiba groups over a period of $8 \mathrm{wks}$ in the field (Table 1). Whenever possible observations took place between 0600 and $1600 \mathrm{hrs}$, with breaks for breakfast and lunch. Instantaneous sampling (focal and group scans) was employed based on the conclusions of Rose (2000).

Instantaneous focal animal and group scan sampling: For focal animal sampling, the adult monkey in clearest view was chosen and observed for $30 \mathrm{~min}$, recording his/her specific behavior at 60 s intervals. A prepared ethogram developed by Rose (2000) was utilized which identifies specific behaviors, as well as groups of more general "Activity Classes" (Table 2). Alterations to the ethogram prepared by Rose (2000) were also made, placing "Alarm Call" under "Activity Class 4: Aggression toward Other Species." "Activity Class 5: Eating" was also combined with "Activity Class 6: Foraging" for analysis because they are closely linked in overall activity budgets, and eating

TABLE 1

Sampling intensity for each monkey group by number of days, and sampling method. Curú Wildlife Refuge and Hacienda. March-April 2012

\begin{tabular}{lcccc} 
Group & $\begin{array}{c}\text { Number of Days } \\
\text { of Observation }\end{array}$ & $\begin{array}{c}\text { Total Hours } \\
\text { of Focal Data }\end{array}$ & $\begin{array}{c}\text { Total Hours } \\
\text { of Scan Data }\end{array}$ & $\begin{array}{c}\text { Total Hours } \\
\text { Collected }\end{array}$ \\
\hline Finca & 22 & 26.7 & 20.27 & 46.97 \\
Ceiba & 26 & 41.2 & 31.5 & 72.7 \\
Total & $42^{\text {a }}$ & 67.9 & 51.77 & 119.67 \\
\hline
\end{tabular}

${ }^{a}$ For the first $8 \mathrm{~d}$ of observation, behavior was observed in both sides of CWR because the alternate-day system had not been initiated. 
TABLE 2

Summary of the 10 activity classes used according to an ethogram prepared by Rose (2000)

\begin{tabular}{cll} 
Class Number & \multicolumn{1}{c}{ Activity Class Title } & \multicolumn{1}{c}{ Example Behaviors } \\
1 & Affiliation & Grooming, playing, huddling, hugging \\
2 & Agonism & Chasing, biting, threatening, staring \\
3 & Sexual Behavior & Soliciting, mounting, courtship, mating \\
4 & Aggression toward other species & Alarm call, threatening, alliance, mob \\
5 & Eat & Pick (food), process (food), catch and eat, drink \\
6 & Forage & Visual forage, manual forage, explore, sample \\
7 & Movement & Move, travel \\
8 & Inactive & Resting \\
9 & Scan & Vigilance, scan and call, watch group \\
10 & Other & Fur rub, nurse, share food, self-groom \\
\hline
\end{tabular}

and foraging behaviors may be easily confused during observation.

In the event of losing sight of the initial focal animal, the next adult monkey closest to the researcher was identified and observation continued with that individual for the duration of the interval. If the focal animal was moving but did not appear to be fleeing, it would be followed. If the focal animal attempted to flee, observations would be discontinued so as not to appear as a predator and potentially increase stress on the animal. If the entire troop traveled away, observation was stopped, the time of troop departure was recorded and behavioral observations would cease.

For group scan collection, rather than recording specific behaviors, the number of individuals exhibiting a behavior from a certain Activity Class were tallied, also at 60 s intervals. For example, Activity Class 1 is "Affiliative Behavior," meaning that if three monkeys were observed grooming one another, and two monkeys playing, " 5 " would be recorded under "Class 1," rather than distinguishing specific behaviors.

Equipment: A GPS device (GARMIN, Etrex Venture, www.garmin.com) was used to record coordinates of the 13 data collection sites (five Ceiba and eight Finca sites). The five Ceiba sites were located on tourist trails and the center of human development. The eight Finca sites were located on maintenance trails that were typically unvisited by humans other than the occasional visit by a refuge employee. Binoculars were used to view monkeys high up in the trees and a wristwatch was used to time observation intervals.

Statistical analyses were performed to examine the relationship of monkey behavior towards human behavior or proximity to human activity. We estimated the difference in mean distances of each monkey group to farm/ refuge headquarters with a parametric oneway ANOVA. We tested the independence of behavioral activity classes with monkey groups with a contingency table (Sokal \& Rohlf, 1995). Additionally, I estimated differences in mean frequency of occurrence of behavioral activity "Class 4" between monkey groups with a parametric, one-way ANOVA. Variables were transformed with $\log _{10}$ if not homogeneous between groups (Sokal \& Rohlf, 1995). Statistical tests were run with Statgraphics Centurion XVI (Statpoint Technologies, Inc., 2011).

\section{RESULTS}

A daily mean of $2.84 \mathrm{hrs}$ of observations were collected. Monkeys in the Ceiba group were observed for more hours because they were easier to find (Table 1).

Monkey group distribution: Mean distance from the farm/refuge headquarters was greater for the Finca group monkeys 
( $\bar{x}=0.99 \mathrm{~km} ; \log _{10} \bar{x}=-0.025$ ) than for the Ceiba group $\left(\bar{x}=0.71 \mathrm{~km} ; \log _{10} \bar{x}=-0.056\right) \quad(\mathrm{F}=10.9$; $\mathrm{df}=1,130 ; \mathrm{p}=0.0013)$ (Fig. 1).

Focal Animal: Frequencies of occurrence of the nine activity classes (Class 3 [Sexual Behavior] was omitted for lack of data) were dependent on monkey group $\left(\mathrm{X}^{2}=1665, \mathrm{df}=8\right.$, $\mathrm{p}<0.0001$ ) (Fig. 2). Classes 1, 4, $5 \& 6$, and 7 were most relevant to my study objectives.

\section{Class 1: Affiliative behavior between} individuals: Mean number of affiliative behaviors (e.g. grooming, playing etc.) per 30-min interval was larger for the Ceiba group $(\bar{x}=6.3)$ than for the Finca group $(\bar{x}=4.5)$, but not significantly so $(\mathrm{F}=0.44 ; \mathrm{df}=1,50 ; \mathrm{p}=0.51)$.
Class 4: Aggressive behavior toward

humans: Mean log-transformed number of aggressive behaviors toward other species (e.g. physical displays, alarm calls etc.) per $30 \mathrm{~min}$ interval was significantly greater for the Finca group $\left(\log _{10} \bar{x}=0.83\right)$ than for the Ceiba group $\left(\log _{10} \bar{x}=0.07\right) \quad(\mathrm{F}=39.04 ; \mathrm{df}=1,58 ; \mathrm{p}<0.0001)$ (Fig. 3). Additionally, in the Finca group 478 instances of aggression were recorded, while only 15 instances were recorded in the Ceiba group.

Classes 5 and 6: Eating and Foraging: Mean frequency of occurrence of eating/ foraging behaviors (e.g. eat, drink, search in substrate etc.) per $30 \mathrm{~min}$ interval was greater

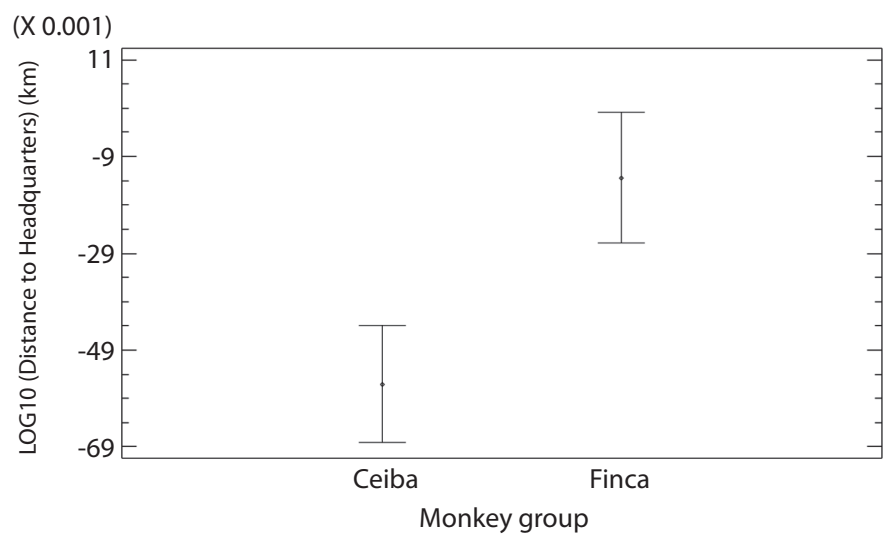

Fig. 1. Mean distance to center of human activity (farm/refuge headquarters) for each monkey group for instantaneous focal animal observations. Vertical intervals are \pm 1 least significant $95 \%$ confidence intervals. Un-transformed means: (Ceiba 0.705km, Finca 0.990km). Curú Wildlife Refuge and Hacienda, Puntarenas, Costa Rica. March-April 2012.

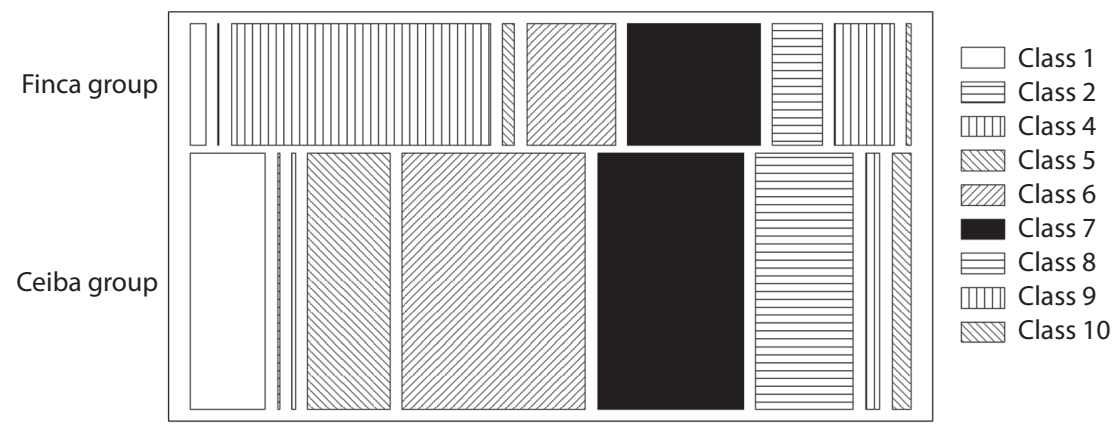

Fig. 2. Mosaic plot of frequency of occurrence of each activity class for each monkey group for instantaneous focal animal observations. Behavioral class definitions follow Table 1. Curú Wildlife Refuge and Hacienda, Puntarenas, Costa Rica. March-April 2012. 


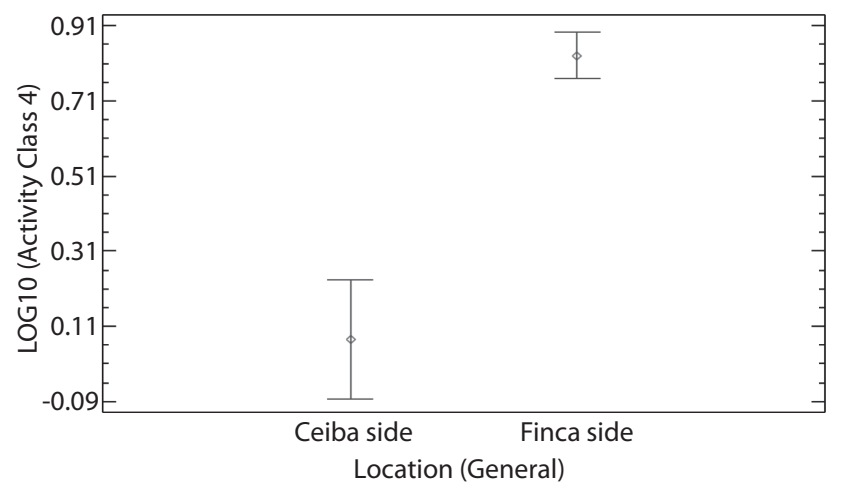

Fig. 3. Mean frequency of occurrence per 30-min interval of Class 4 (Aggression Toward Other Species) ( $\left.\log _{10}\right)$ between monkey groups for instantaneous focal animal observations. Vertical lines \pm 1 LSD $95 \%$ confidence intervals. Curú Wildlife Refuge and Hacienda, Puntarenas, Costa Rica. March-April 2012.

for the Ceiba group $(\bar{x}=11.1)$ than for the Finca group $(\bar{x}=4.27)(\mathrm{F}=40.4 ; \mathrm{df}=1,149 ; \mathrm{p}<0.0001)$.

Activity Class 7: Movement: Mean number of movement-related behaviors per 30 min interval was greater for the Finca group $(\bar{x}=6.7)$ than the Ceiba group $(\bar{x}=5.9)$, but not significantly so $(\mathrm{F}=1.08 ; \mathrm{df}=1,149 ; \mathrm{p}=0.30)$.

Group scan: The activity budgets of the Finca group and Ceiba group differed significantly, according to scan data $\left(X^{2}=5798, d f=8\right.$, $\mathrm{p}<0.0001$ ).

\section{DISCUSSION}

The Ceiba monkey group was clearly more habituated to human presence than the Finca group. The relative lack of aggression and fear response toward other species, specifically humans, in the Ceiba group suggests that Ceiba monkeys do not fear humans as potential predators nor view them as dangerous competitors for resources. The activity budget I (SEW) gathered from the Ceiba group more closely matched behavioral data of Rose (2000) than did the activity budget of the Finca group. The slight discrepancy between the Ceiba group behavior and that of the monkeys Rose (2000) studied is most likely a result of personal methodological errors such as misidentifying behaviors. I (SEW) imagine that with more hours, the Ceiba group data would more closely resemble the data collected by Rose (2000).

The Finca group, on the other hand, clearly maintained fear of humans, which is why the monkeys in the Finca acted aggressively toward me in essentially every interval I (SEW) completed. The Finca group is clearly not habituated as evidenced by their high rates of aggression toward other species, and their general attention to humans. The Finca group data greatly differed from data obtained by Rose (2000), on fully habituated monkeys, showing Finca monkeys not as accustomed to human presence. This is to be expected as the Ceiba monkeys spent most of their day on commonly followed tourist trails or in the center of human activity. Because the Finca monkeys rarely come into contact with humans, it logically follows that they would view any human as a threat. Indeed, initial reaction to habituation in primates includes increased rates of vocalization and increased aggression (Turner, 2005).

It is unclear what the consequences are of increased habituation of the Ceiba monkey group, as far as monkey health, visitor safety, and future conservation. Though little data is available concerning long-term effects of habituating New World primates, some studies (Altmann \& Muruthi, 1988) of the Great Apes suggest that habituation can have long-term 
impacts on behavior, particularly feeding and social structure (Turner, 2005). Because the owner of CWR routinely feeds the habituated monkeys, it is possible that they will become over-habituated in the future. It is also difficult to control the number of individuals that become habituated, and it is possible for habituation to spread from a few individuals to an entire population (Turner, 2005). Because white-faced capuchin troops often overlap in home range, the spread of habituation is a distinct possibility and thus a subject of concern.

First, overly habituated monkeys can become a threat to human safety and human health. They can serve as disease vectors (Crofoot et al., 2009) and they can be physically aggressive (Hall, 2000). While the Ceiba monkeys did not necessarily express evidence of over-habituation, two accounts of personal attack by white-faced capuchins were observed. In both of these instances, all humans involved were acting neutrally and not attempting to excite the monkeys in any way. Both accounts involved large male chasing researchers. However, no humans or monkeys were harmed in either case. While these cases are only anecdotal, and therefore not appropriate for statistical analysis, they are still relevant.

Secondly, over-habituated monkeys can jeopardize their own health and safety by increasing exposure to objects associated with humans and development, such as moving vehicles, dangerous machines, and power lines. Additionally, if habituated monkeys enter areas of human development, they can be exposed to human litter such as medical waste and broken glass, which I (SEW) witnessed at CWR. Third, they can alter their behavior, which might have negative effects in the long-term regarding reproduction and foraging patterns (Altmann, \& Muruthi, 1988). Finally, they can become bothersome to the point of causing economic loss. They can cause damage, and steal food or valuable objects.

Current consequences of over-habituated white-faced capuchins can already be observed at numerous tourist attractions at sites all around Costa Rica. At Punta Leona Hotel and
Resort, located just North of Jacó in Puntarenas province, dozens of white-faced capuchins can be seen from the primary eatery of the hotel (Van Hulle, \& Vaughan, 2009). The monkeys at Punta Leona have become habituated to the point that they have absolutely no fear of humans, which has resulted in their stealing of food directly from restaurant tables and closer interactions between humans and monkeys (Van Hulle, \& Vaughan, 2009). In Manuel Antonio National Park, white-faced capuchins are, similarly, totally unafraid of humans, which has resulted in physical aggression towards humans, as well as theft of objects humans leave unattended (Hall, 2000). At CRW, the white-faced capuchins are not as aggressive and fearless as those at Punta Leona or Manuel Antonio, but it is possible that with continued exposure to humans and human activity, in addition to receiving provisions, they could reach that point.

Westin (2007) suggested with mantled howlers in Suriname, that "although [howlers] may have been altering their behavioral patterns in response to tourist presence, they appeared not to be suffering behaviorally... this general monkey ability to remain flexible and adaptable in the face of habitat change or disturbance (in this case through tourism) mirrors that found in other populations of howlers, and at other sites" (Naveda et al., 2008). This may indeed be the case for white-faced capuchins in Costa Rica, but with very little longterm, multi-generational data investigating the effects of habituation, we cannot know for certain. Research into the topic of human-primate interaction, particularly in a tourist context, should be proactive, rather than reactive. Thus, while fully habituating white-faced capuchins is not wholly negative (it does, after all, allow primatologists an up-close look at social hierarchy and social learning), it does pose potential problems, especially if habituated monkeys are not monitored closely. Furthermore, as so little research is published on the process of habituation, because it is typically viewed as a "means to an end," it is becoming critically 
important to investigate the effects of habituation (Turner, 2005).

Over-habituation poses a problem for conservation. Ideally, both monkeys and visitors on protected lands remain safe. At CWR, the monkeys and humans appear to be able to inhabit the same area safely, which may be a result of the owner providing them with a consistent food source. However, while in the present moment CWR seems to handle habituated monkeys safely and well, it is important to remain vigilant in achieving conservation goals that primarily benefit the capuchin populations.

Perhaps the best example of primate management in relation to exposure to humans comes from India, where large populations of rhesus macaques (Macaca mulatta) have become a pressing issue in many urban areas. The sprawl of human development has overlapped with macaque populations for an extended period of time, becoming not only pests, but also actual dangerous threats. Rhesus monkeys in certain urban areas of India have become hyper-aggressive, biting and injuring dozens of people each day (Ekwal, Yahya, \& Malik, 2002). In order to lessen the negative effects of monkey-human interactions, 1300 individual monkeys were translocated to a protected wildlife area far away from human development. A post-translocated study showed that the monkeys had adapted to the new environment and seemed to exhibit no negative responses (Ekwal et al., 2002).

In Kenya, where semi-provisioned baboons near tourist lodges have become overhabituated to the point of being viewed as pests, removal of animals has been less successful (Altmann, \& Muruthi, 1988). When part of a population had been eradicated from an area of human development, another population typically relocated to gain access to the semi-provisioned habitat. Thus, the only sure way to limit the conflict between the humans and primates is to limit the offending human behavior, rather than eradicate the primates (Altmann, \& Muruthi, 1988).
Though the white-faced capuchins in Costa Rica are not as dangerous and threatening as the rhesus monkeys in Northern India, translocation of certain populations is a viable option. With extensive protected land, adaptable white-faced capuchins could be relocated to more isolated areas. While this would not undo more subtle consequences of over-habituation, it could prevent more serious, long-term consequences. Additionally, stricter rules limiting accidental or deliberate human provisioning would help prevent the negative effects of over-habituation.

In future studies in CWR, it would be informative to focus on the Ceiba monkey group in order to more clearly assess potential over-habituation. Because CWR is an ecotourist site, it draws humans and primates into the same physical space. This overlap leads to habituation of the non-human primates, and in the long term could lead to over-habituation. Currently, CWR is seen as a successful site of conservation, but data suggests that in the future, primates could become over-habituated without stricter mitigation of human contact. The application of ethnoprimatology-a field that combines quantitative assessment of primate behavior with qualitative assessment of how humans perceive the animals and their conservation - is critical for CWR. Even though white-faced capuchins are recognized as "non-threatened" this is not necessarily accurate. Anthropogenic influences can lead to change in primates over time, even in species that are officially described as "least concern" by the IUCN.

\section{ACKNOWLEDGMENTS}

Many thanks to Scott Legge for advice, support, and editing. Thanks go to Chris Vaughan for providing useful feedback on my proposal for the project and to ACM for assistance in facilitating field research. We thank the Schutt family at Curu Wildlife Refuge and Hacienda for providing lodging, and this research site. 


\section{RESUMEN}

Ecoturismo y habituación de primates: variación en comportamiento de dos grupos de monos carablanca (Cebus capucinus) en Costa Rica. El aumento de actividades ecoturísticas en Costa Rica durante los últimos 20 años ha ocasionado que más y más personas entren en contacto directo y cercano con varias especies de vida silvestre. Una de estas especies es el mono carablanca (Cebus capuci$n u s)$, que es muy gregario y, al pasar el tiempo, tiende a acercarse a los humanos y sus instalaciones. Tal contacto tiene ventajas y desventajas para la industria del ecoturismo. Observamos monos carablanca con el fin de evaluar el impacto de la presencia humana y la infraestructura en el comportamiento de estos animales, enfocando los comportamientos de agresión, acicalamiento y forrajeo para determinar el grado de habituación excesiva de las poblaciones de monos capuchinos en el Refugio de Vida Silvestre Curú, Puntarenas, Costa Rica. Aunque no existen parámetros específicos de comportamiento para medir la habituación excesiva, se puede definir esta condición como un estado en que los primates no humanos no solamente pierdan su temor a los humanos, sino que también incluyen a las personas activamente en sus interacciones sociales o las consideran como una fuente de alimentación. Los monos carablanca fueron observados a través del muestreo instantáneo focal y por escaneo grupal durante ocho semanas de marzo y abril de 2012. Dos grupos (aproximadamente 20-30 individuos cada uno) fueron observados; uno cerca del desarrollo turístico en la parte suroeste del refugio, que representó una población habituada que de manera regular comía, descansaba y se acicalaba en presencia de humanos; el segundo grupo, que se observó en el noreste del refugio, no visitaba el centro de actividad humana y mostraba temor hacia los humanos. El grupo habituado mostró significativamente menos ocasiones de comportamiento amenazante ante la presencia humana $(\mathrm{p}<0.0001)$ y empleó más tiempo comiendo y buscando alimento $(\mathrm{p}<0.0001)$. Aunque el grupo de habituados en Curú probablemente no tenga habituación excesiva, esta condición podría surgir más adelante, especialmente si aumenta el desarrollo, y en particular el ecoturismo. La habituación excesiva es un problema que afecta a los monos carablanca en ciertos sitios secoturísticos de Costa Rica. Es de suma importancia que las consecuencias de la habituación excesiva se estudien más a fondo, principalmente en las áreas donde las actividades ecoturísticas atraen visitantes a los hábitats de la vida silvestre.

Palabras clave: Cebus capucinus, Costa Rica, ecoturismo, habituación, habituación excesiva, mono carablanca.

\section{REFERENCES}

Altmann, J. \& Muruthi, P. (1988). Differences in daily life between semiprovisioned and wild-feeding baboons. American Journal of Primatology, 15, 213-221.
Buchsbaum, B. D. (2004). Ecotourism and Sustainable Development in Costa Rica. (Unpublished major paper). Virginia Polytechnic Institute and State University, Blacksburg, VA., USA. Retrieved from http:// scholar.lib.vt.edu/theses/available/etd-05052004171907/unrestricted/EcotourismCostRica.pdf

Crofoot, M. C., Norton, T. M., Lessnau, R. G., Viner, T. C., Chen, T. C., Mazzaro, L. M., \& Yabsley, M. (2009). Field anesthesia and health assessment of freeranging Cebus capucinus in Panama. International Journal of Primatology, 30(1), 125-141.

Ekwal, I., Yahya, H. S. A., \& Malik, I. (2002). A successful mass translocation of commensal rhesus monkeys Macaca mulatta in Vrindaban, India. Oryx, 36, 87-93.

Gall, T. L. \& Hobby, J. M. (Eds.). (2007). Worldmark encyclopedia of the nations (pp. 173-360). Detroit, MI, USA: Gale.

Hall, T. (2000). The effects of tourism on white-faced capuchins (Cebus capucinus) in Manuel Antonio National Park, Puntarenas, Costa Rica. (Unpublished undergraduate thesis). Colorado College, Colorado Springs, Colorado, USA.

Honey, M. (2003). Giving a grade to Costa Rica's green tourism. NACLA Report on the Americas, 36(6), 39.

IMN (Instituto Meterológico Nacional de Costa Rica). (2012). Datos climáticos de Puntarenas. Retrieved from http://www.imn.ac.cr/imn/MainAdmin.aspx? EVENTTARGET $=$ ClimaCiudad $\&$ CIUDAD $=6$

IUCN (International Union for Conservation of Nature). (2012). IUCN Red List of Threatened Species. Version 2012.2. Gland, Switzerland: IUCN.

Jack, K. M. (2010). The Cebines: Toward an explanation of variable social structure. In C. Campbell, A. Fuentes, K. MacKinnon, S. Bearder, \& R. Stumpf (Eds.), Primates in perspective (pp. 107-123). Cary, NC, USA: Oxford University.

Naveda, A., de Thoisy, B., Richard-Hansen, C., Torres, D. A., Salas, L., Wallance, R., Chalukian, S., \& de Bustos, S. (2008). Tapirus terrestris. In IUCN, IUCN Red List of Threatened Species. Version 2011.2. Retrieved from http://www.iucnredlist.org/details/21474/0

Perry, S., Baker, M., Fedigan, L., Gros-Louis, J., Jack, K., MacKinnon, K. C., Manson, J. H., Panger, M., Pyle, K., \& Rose, L. (2003). Social conventions in wild white-faced capuchin monkeys: Evidence for traditions in a Neotropical primate. Current Anthropology, 44(2), 241-268.

Rose, L. (2000). Behavioral sampling in the field: Continuous focal versus focal interval sampling. Behaviour, 137(2), 153-180.

Schutt, A. \& Vaughan, C. (1995). Incorporating wildlife into development: The case of the Curú Wildlife Refuge and Farm, Costa Rica. In J. Bissonette \& P. Krausmann (Eds.), Integrating people and wildlife 
for a sustainable future (pp. 250-254). Bethesda, MD, USA: Wildlife Society.

Sokal, R. R. \& Rohlf, F. J. (1995). Biometry: The principles and practice of statistics in biological research. NY, USA: W. H. Freeman and Co.

Statpoint Technologies, Inc. (2011). Statgraphics Centurion [computer software]. Available from http://www. statgraphics.com

Stem, C. J., Lassoie, J. P., Lee, D. R., Deshler, D. D., \& Schelhas, J. W. (2003). Community participation in ecotourism benefits: The link to conservation practices and perspectives. Society Natural Resources, 16(5), 387-413.

Turner, T. R. (2005). Biological anthropology and ethics: From repatriation to genetic identity. Albany, NY, USA: State University of New York.

Van Hulle, M. \& Vaughan, C. (2009). The effect of human development on mammal populations of the Punta
Leona private wildlife refuge, Costa Rica. Revista de Biologia Tropical, 57(1-2), 441-449.

Vogel, E. R. (2005). Rank differences in energy intake rates in white-faced capuchin monkeys, Cebus capucinus: The effects of contest competition. Behavioral Ecology and Sociobiology, 58(4), 333-344.

Westin, J. L. (2007). Effects of ecotourism on the behavior and health of red howler monkeys (Alouatta seniculus) in Suriname. (Unpublished Ph.D. dissertation). University of Michigan, Ann Arbor, MI, USA. Retrieved from http://deepblue.lib.umich.edu/handle $/ 2027.42 / 57667$ ?show=full

Williams, H. E. \& Vaughan, C. (2001). White-faced monkey (Cebus capucinus) ecology and management in Neotropical agricultural landscapes during the dry season. Revista de Biología Tropical, 49(3-4), 1199-1206. 